\title{
ANALYZING INTERNATIONAL READINESS OF SMALL AND MEDIUM-SIZED ENTERPRISES
}

\author{
Hamidizadeh, M. R., Zargaranyazd, M.
}

\begin{abstract}
Internationalization has different connotations for different social sciences and its social, economic and cultural impacts have been examined by a number of studies. While firms' internationalization processes have been understood as being dynamic, the concept of international readiness has rarely been the main focus of research efforts, which until a decade ago, focused principally on explaining sequences of entry modes and choices of markets. The emergence of the study of international entrepreneurship has enhanced the role of readiness. This study reviews the concept of international readiness by experimental and theoretical studies. Axioms in this research are based on content analysis. The framework incorporates measures to evaluate SMEs' international readiness. The paper concludes with a research agenda as a guide for future work on considering the readiness as a critical phase before the internationalization process.
\end{abstract}

JEL classification: M31, F23, F53

Keywords: internationalization; international readiness; international motives; small and medium-sized enterprises.

\section{Introduction}

Internationalization has lessened barriers to enter foreign markets. Entrepreneurs and small to medium size enterprises (SMEs) are inspired to "go international", and firms are increasingly influenced into pursuing foreign markets. Internationalization is a main dimension of a firm's growth. Market liberalization and digitization have encouraged large, small and medium-sized corporations to operate beyond their national borders and compete with each other. There are many motives and obstacles to entering international markets, which have led to many questions regarding the "readiness" of these firms to guarantee international activities and successfully conduct the internationalization process (Béliveau and Haskell, 2007). Comparatively few studies have examined international preparation. This study addresses a knowledge gap according to the SMEs internationalization process. Drawing on several strands of literature, including the International Readiness Diagnosis (IRD) (Béliveau and Haskell, 2007), Internationalization Readiness Index (IRI) (Tan et al, 2008), International Business Assessment Model (IBAM) (Carroll, 2012), we develop a model for analyzing internationalization readiness by reviewing and concluding the dimensional constructs of it based on experimental and theoretical past studies. Then, our conclusions will be presented in the framework of axioms which show our content analysis. Thus, the framework incorporates measures to evaluate SMEs' international readiness. The framework incorporates three dimensions that are related indices 1) marketing/ operational, 2) functional, and 3) managerial commitment readiness to evaluate the internationalization readiness of SME activities. Axioms are developed, based on the framework.

\section{Literature Review}

During the few past decades, "international readiness" has been used as a popular term in economic circles (Casillas and Acedo, 2013). The early work of Cavusgil (1990) clearly examined the internationalization readiness of firms, which identified software (CORE: Company Readiness to Export) that assesses a firm's export preparedness. Indeed, Cavusgil (1990) distinguished export readiness into two key dimensions: organizational (which includes top management commitment, the 
availability of human and financial resources, and the wholeness of the organizational structure) and product (e.g. product adaptation, design, and positioning).

Liesch and Knight (1999) considered the topic of readiness, highlighting the function of information internalization in the internationalization process of SMEs. They defined this concept as "being a function of its state of awareness on foreign market(s) and the means for entering them" (Liesch and Knight, 1999). According to the definition, the accessibility of information and knowledge about foreign markets is essential for a firm's preparedness for internationalization.

Internationalization readiness is identified as a firm's potential transition from an entirely domestic firm into an international one. Liesch and Knight (1999, p.386) assert that "readiness for involvement in international markets can be interpreted as being a function of its state of awareness on target foreign market(s) and the means for entering them". In this study, we define internationalization readiness as a firm's preparedness and propensity to commence export activities overseas.

\section{Analyzing Models and Axioms}

Several international readiness studies have been done in this field. From the early work of Béliveau and Haskell (2007) through the study by Tan et al (2008) to the more recent research by Carroll (2012), they evaluated the international readiness of SMEs in different aspects. Here, we will analyze some models in the field of internationalization readiness as follows.

Béliveau and Haskell (2007) suggested the development of the International Readiness Diagnosis (IRD) for small and medium size firms. The purpose of the IRD is to evaluate different aspects of a firm's preparedness for international activities on the five dimensions identified. The first dimension will focus on management factors (e.g. management attitudes, perceptions, and characteristics) (Sutinen, 1996; Reid, 1991; Nummela et al, 2004; Hart and Tzokas, 1999; Crick, Jones, 2000; Francis, Collins-Dodd, 2000; Knight, 2000; Yip et al, 2000). The second dimension of the IRD will be based on variables related to the firm's competencies and characteristics (both financial and non-financial). The third dimension will focus on industry characteristics (e.g. stability, government assistance, available financing), domestic market characteristics (e.g. potential market for products of the firm, competitiveness, foreseen difficulties) and foreign market characteristics (e.g. presence of market obstacles, release of identifying and working with foreign partners). The fourth dimension of IRD will be based on different aspects of the marketing strategy of the firm (strategic alliances, order of entry, mode of entry, size of entry and timing of entry, degree of export planning, export marketing information, product adaptation, price competitiveness and different factors influencing the degree of competitiveness). The fifth dimension will focus on the Export Readiness Diagnosis based on firm performance (financial and non-financial) after the firm commences its international activities.

Furthermore, Tan, Brewer and Liesch (2008) explained the construction of an Internationalization Readiness Index (IRI) as an analytical tool for assessing a firm's preparedness to initiate international operations. There are four major principle concepts to the ability of a firm to start internationalization of its activities: 1) stimuli (which act as motives, incentives, triggering cues or attention evokers (Leonidou, 1998); 2) attitudinal/ psychological commitment (the decision maker's psychological and attitudinal stake connected with drivers and involvement); 3) Resources (a firm's tangible resources such as a firm's financial or human-related characteristics (Hitt et al, 2012) product characteristics such as features and quality (Khalili, 1991; Louter et al, 1991), investment in R\&D (Reid, 1991), and technological characteristics (Aaby and Slater, 1989); 4) lateral rigidity (a behavioral characteristics that cause inflexibility in decision-making).

The International Business Assessment Model (IBAM) is a systematic tool for evaluating SMEs' international business capabilities and the fields of progress (Carroll, 2012). This method has been constructed to meet the increasing demand of business without national borders. IBAM offers the company an explicit and realistic image of what is accomplished well and what should be enhanced to improve success in foreign market(s). IBAM examination is based on four fields of internationalization: 1) market deduction; 2) customer understanding; 3) business knowledge; 4) entry mode. Overall evaluation focuses on five different processes: management process; innovation and development process; consumer control process; product management process; and information system process. With considering four fields of internationalization and five overall processes, there are 20 assessable subjects. Eventually, all firms' internal activities which are related to the internationalization process will be covered entirely (Carroll, 2012).

In this study, we employ three dimensions for analyzing internationalization readiness. Constructing on the export obstacles by related literature, internationalization readiness is represented using three measures: marketing/operational readiness (Leonidou, 1995), functional readiness (Suarez-Ortega, 2003), managerial 
commitment readiness (e.g., Nummela et al., 2004). Indeed, marketing/operational and functional readiness will be categorized as "physical" or "hard" forms. Managerial commitment readiness (Nummela et al, 2004) is more of a "soft" or "psychological" sort of internationalization preparedness. Drawing on the above discussion, the following axioms will be conducted:

Marketing/operational readiness is defined as obtaining reliable foreign representation abroad; absence of tough competition internationally; low transportation costs; ability to adapt to customer preferences overseas; ability to offer competitive prices overseas; short distance from overseas market; and appropriate export strategy.

Axiom 1: Marketing/operational readiness is a significant criterion to measure the international readiness of SMEs.

Functional Readiness is defined as familiarity with export documentation; no fear of the unknown export venture; availability of a unique and differentiated product; availability of qualified export personnel; and availability of financial resources.

Axiom 2: Functional readiness is a significant criterion to measure the international readiness of SMEs.
Managerial Commitment Readiness is defined as appreciation of the importance of export; market to the firm's overall success; devotion of managerial time to exporting; international outlook among export decision makers; and incorporation of exporting into the overall firm strategy.

Axiom 3: Managerial commitment readiness is a significant criterion to measure the international readiness of SMEs.

This framework represents environmental factors. The international business environment influences the marketing strategies of a firm. These pressures that surround businesses influence their life and their development of the enterprises. Companies that want to enhance their activities in international markets need to explore the business environment which has a significant effect on SMEs' readiness to enter the foreign markets. Environmental factors play an important role on the speed of the internationalization process. The notion of speed associates to the length of time over (or within) which particular aims are attained, and is mostly measured as an amount between a particular disparity and a specific unit of time. Thus, speed links two basic components:

Figure 1: Conceptual Model

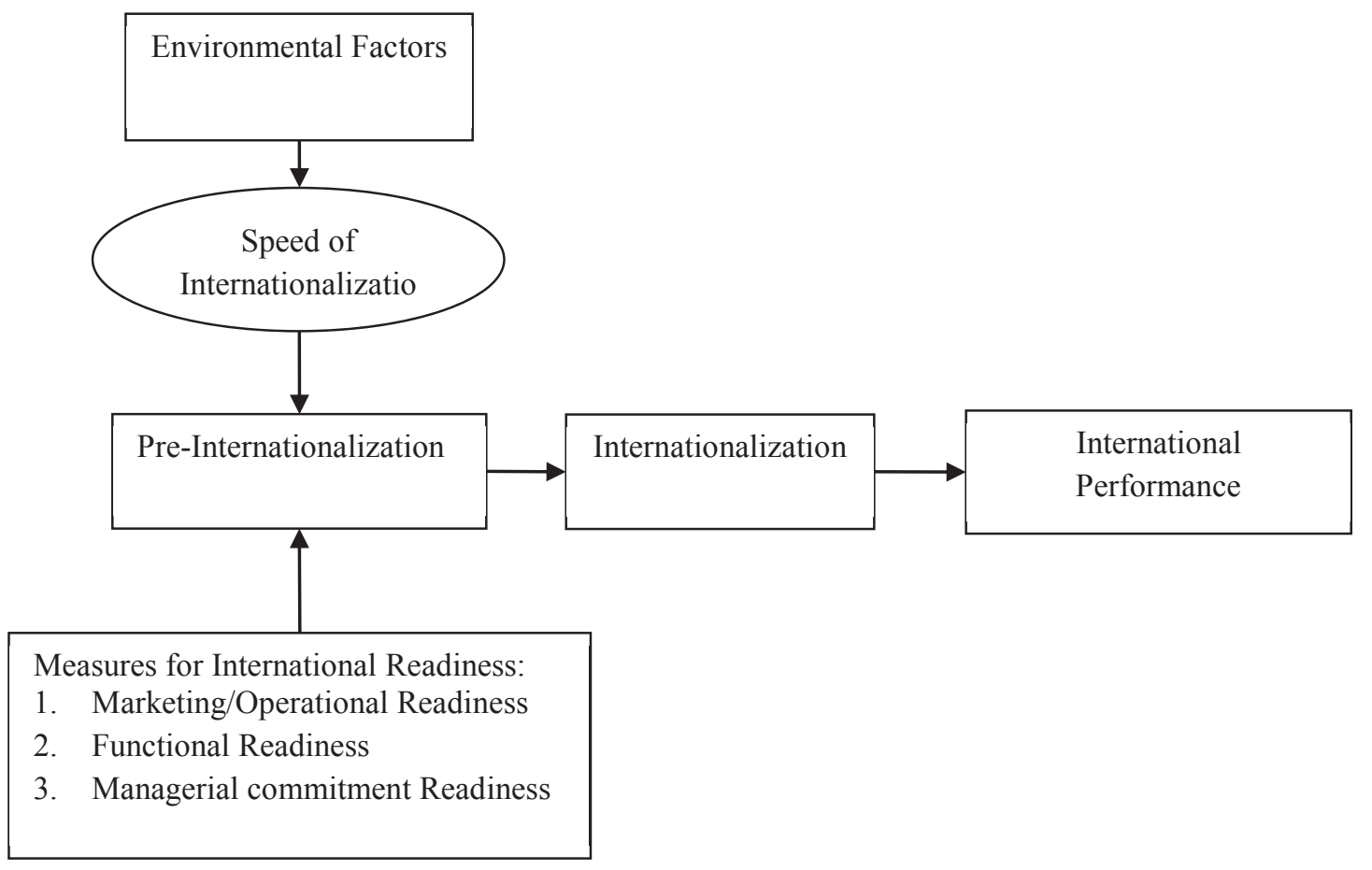

Source: Gerschewski et al, 2007; Hamidizadeh and Zargaranyazd, 2014; Hamidizadeh and Zargaranyazd, 2015) 
the first is change within a specific dimension, the second a specific pointer of time (Hamidizadeh and Zargaranyazd, 2015).

There are uncontrollable forces such as external forces upon which management has no direct control, although it can exert some influence. Internal forces are controllable forces upon which the management administers to adapt to changes in the uncontrollable forces (Zekiri and Angelova, 2011). Furthermore, this framework incorporates marketing/operational readiness, functional readiness and managerial commitment readiness to evaluate internationalization preparedness of SMEs.

\section{Results}

We have developed a conceptual framework for international readiness, and shown its relationship with international performance. A key finding of our study is that international readiness is a multi-faceted construct. As shown by content analyzing, the different sets of variables serve as effective predictors for each of the three identified types of international readiness. For instance, the formalization of international activities is found to be positively related to marketing/operational and managerial commitment readiness, and significantly associated with functional readiness. Similar results are observed for proactive international motives, which are consistent with previous studies (Leonidou, 1995), and emphasize the importance of the motivation to commence internationalization. The international readiness measurement permits sharing with entrepreneurs what researchers have learned over the years about successful internationalization. It presents a win-win approach whereby entrepreneurs are confronted with the latest research findings concerning the determinants of success, how they can be applied, how the entrepreneurial firm can attempt to increase its chances of success. In return, it will permit researchers to study "cases" over time and to gain greater depth of knowledge concerning not just the presence of success-related characteristics, but also an understanding of how entrepreneurs move the firm toward international growth and success by adjusting their levels of readiness. Results would potentially help to validate activities, in a qualitative and longitudinal way, by today's knowledge base. Therefore, it is expected that they could catch a rich new opportunity for research in our exploration of international entrepreneurship.

\section{Conclusion}

Analysis procedures will allow managers/researchers to judge the firm's actual situation or position on each subject presented in relation to the optimal level. This comparison creates an objective to be discussed and attained and, if the process is repeated, documents the degree of "progress" toward the level deemed "optimal" for each attribute. Comparison of theses "gaps" (between actual and optimal levels) across members of management teams and at different levels of management is a fruitful exercise that has been well received by SMEs using the Export Diagnosis. The researcher's discussion should be a learning experience for the manager/entrepreneur, thus the documented success factors related to internationalization can be generalized and applied by small businesses, becoming a learning tool for managers.

\section{References}

Aaby, N., Slater, S. F. (1989). Management influences on export performance: a review of empirical literature 1978-88. International Marketing Review, 6(4): 7-26.

Béliveau, D., CA, C., Haskell, N. (2007). The International Readiness Diagnosis: A Modular Framework to Diagnose and Track.

Carroll, U. (2012). Internal Readiness at SMEs for Internationalization: A Case Study: IBAM Internationalization Analysis in YKO Project.

Casillas, J. C., Acedo, F. J. (2013). Speed in the Internationalization Process of the Firm. International Journal of Management Reviews, 15(1): 15-29.

Cavusgil, S. T. (1990). Assessment of company readiness to export, in International Marketing Strategy., ed. Thorelli, H. B., Cavusgil, S. T., Oxford: Pergamon Press.

Czinkota, M. R., Ronkainen, I. A., Moffett, M. H. (2005). International Business. 7th edition. South Western part of the Thompson Corporation. USA.

Crick, D., Jones, M. V. (2000). Small high-technology firms and international high technology markets. Journal of International Marketing, 8(2): 63-85.

Francis, J., C. Collins-Dodd (2000). The impact of firms ${ }^{6}$ expert orientation on the export performance of high-tech small and medium-sized enterprises. Journal of International Marketing, 8(3): 84-103.

Gerschewski, S., Rose, E. L., Scott-Kennel, J. (2007). Understanding Pre-export Behavior of Small and Medium-sized Firms in New Zealand: Towards a Model of Export Readiness. Unpublished Master Thesis, Victoria University of Wellington, Wellington. 
Hart, S., Tzokas, N. (1999). The impact of marketing research activity on SME export performance: evidence from the UK. Journal of Small Business Management, 37: 63-75.

Hitt, M. A., Ireland, R. D., Hoskisson, R. E. (2012). Strategic Management Cases: Competitiveness and Globalization. South-Western Pub.

Hamidizadeh, M. R., Zargaranyazd, M. (2014). Studying the Degree of Readiness of Small and Medium-Sized Enterprises to Enter the International Markets (Case Study: Food companies). International Journal of Engineering, Business and Enterprise Applications (IJEBEA), 7(1): 73-77.

Hamidizadeh, M. R., Zargaranyazd, M. (2015). Strategies for Entering and Maintaining Regional and Global Markets, ShahidBeheshtiIssue, 115-120.

Khalili, S. (1991). Keys to success. International Business, 4(11): 52-55.

Knight, G. (2000). Entrepreneurship and marketing strategy: the SME under globalization. Journal of International Marketing, 8(2): 12-32.

Leonidou, L. C. (1995). Export barriers: non-exporters‘ perceptions. International Marketing Review, 12(1): 4-25.

Leonidou, L. C., Katsikeas, C. S. (1996). The export development process: an integrative review of empirical models. Journal of international business studies, 517-551.

Leonidou, L.C. (1998). Factors Stimulating Export Business: An Empirical Investigation. Journal of Applied Business Research, 14(2): 43-68.

Liesch, P., Knight, G. A. (1999). Information internalization and hurdle rates in small and medium enterprises internationalization, Journal of International Business Studies, 30(1): 383-394.

Louter, P. J., Ouwerkerk, C., Bakker, B. A. (1991). An inquiry into successful exporting. European Journal of Marketing, 25(6): 7-23.

Nakos, G., Brouthers, K. D., Brouthers, L. E. (1998). The impact of firm and managerial characteristics on small and medium-sized Greek firms' export performance. Journal of global marketing, 11(4): 23-47.

Nummela, N., Saarenketo, S. Puumalainen, K. (2004). A global mindset- A prerequisite for successful internationalization? Canadian Journal of Administrative Sciences, 21(1): 51-64.
Philp, N. E. (1998). The export propensity of the very small enterprise (VSE). International Small Business Journal, 16(4): 79-93.

Reid, S. D. (1981). The decision-maker and export entry and expansion. Journal of International Business Studies, 101-112.

Reid, S. D. (1991) .What Do We Know About Export Behavior? in International Marketing: Managerial Issues, Research and Opportunities, ed. Kirpalani, V. H., Storrs: Concordia University.

Sutinen, M. (1996). Pk-yrityksen vientimarkkinointi ja ulkomaankauppa. Helsinki: Pohjois-Savon ammattikorkeakoulu.

Suarez-Ortega, S. (2003). Export Barriers Insights from Small and Medium-Sized Firms. International Small Business Journal, 21(4): 403-419.

Tan, A., Brewer, P., Liesch, P. (2008). Constructing an Internationalization Readiness Index. In Proceedings of AIB 2008 Annual Meeting: Knowledge Development and Exchange in International Business Networks. Academy of International Business.

Vahvaselkä, I. (2009). Kansainvälinenliiketoimintajamarkkinointi. Helsinki: Edita Publishing Oy.

Yip, G. S., Biscarri, J. G., Monti, J. A. (2000). The role of the internationalization process in the performance of newly internationalizing firms. Journal of International Marketing, 8(3): 10-35.

Zekiri, J., Angelova, B. (2011). Factors that Influence Entry Mode Choice in Foreign Markets. European Journal of Social Sciences, 22(4): 572-584.

Knight, G. A. (2001). Entrepreneurship and strategy in the international SME. Journal of International Management, 7(3): 155-171.

Solberg, C. A. (1997). A framework for analysis of strategy development in globalizing markets. Journal of International Marketing, 5(1): 9-30.

Zou, S., Stan, S. (1998). The determinants of export performance: A review of the empirical literature between 1987 and 1997. International Marketing Review, 15(5): 333-356.

Sapienza, H. J., Smith, K. G., Gannon, M. J. (1988). Using subjective evaluations of organizational performance in small business research. American Journal of Small Business, 12(3): 45-53.

Morgan, R. E. (1999). Environmental determinants of export decision making: Conceptual issues regarding the domestic market. European Business Review, 99(5): 323-331. 
Yeoh, P.-Y., Jeong, I.-S. (1995). Contingency relationships between entrepreneurship, export channel structure and environment: A proposed conceptual model of export performance. European Journal of Marketing, 29(8): 95-115.

Piercy, N. (1981). Company internationalization: Active and reactive exporting. European Journal of Marketing, 15(3): 26-40.

\section{Authors}

Mohammad Reza Hamidizadeh Full Professor Management and Accounting Faculty ShahidBeheshti University, Tehran, Iran M-Hamidizadeh@sbu.ac.ir

Maryam Zargaranyazd Research Assistant Management and Accounting Faculty ShahidBeheshti University, Tehran, Iran maryam.zargaran@gmail.com 